DARIUSZ GRZEBELUS

ALICJA MACKO-PODGÓRNI

KATARZYNA STELMACH

KORNELIA KWOLEK

DARIUSZ KADLUCZKA

ZBIGNIEW GAJEWSKI

RAFAL BARAŃSKI

Instytut Biologii Roślin i Biotechnologii, Wydział Biotechnologii i Ogrodnictwa, Uniwersytet Rolniczy w Krakowie

Kierownik Tematu: Prof. dr hab. Dariusz Grzebelus Instytut Biologii Roślin i Biotechnologii, Wydział Biotechnologii i Ogrodnictwa, Uniwersytet Rolniczy w Krakowie, Al. 29 Listopada 54, 31-425 Kraków, tel. 12 6625399, e-mai: d.grzebelus@urk.edu.pl

Prace zostały wykonane $w$ ramach badań podstawowych na rzecz postępu biologicznego $w$ produkcji roślinnej na podstawie decyzji Ministra Rolnictwa $i$ Rozwoju Wsi nr HOR.hn.802.8.2018, Zadanie nr 69.

\title{
Opracowanie i wykorzystanie wysokowydajnych technik selekcji genomowej w doskonaleniu warzyw
}

\section{Development and application of high-throughput techniques for genomic selection in the improvement of vegetable crops}

Słowa kluczowe: genotypowanie, korzeń spichrzowy, mapowanie asocjacyjne, marchew, stres abiotyczny, struktura zmienności genetycznej

\section{FENOTYPOWANIE ROŚLIN}

Cel tematu: określenie fenotypu roślin odpornych na stres zasolenia na poziomie komórkowym.

\section{Opis wyników}

Analiza mikroskopowa przekrojów korzeni roślin kontrolnych wskazała na ich typową budowę i charakterystyczny układ tkanek. U roślin traktowanych $150 \mathrm{mM} \mathrm{NaCl}$ stwierdzono znaczne pogrubienie korzeni. W przypadku roślin F2 zaobserwowano silniejsze grubienie pod wpływem zasolenia niż dla roślin populacji rodzicielskiej tolerancyjnej na stres zasolenia (DLB), co było spowodowane powiększeniem komórek kory pierwotnej, a także większej liczby komórek u roślin F2 (rys. 1). Obserwowano również różnice $\mathrm{w}$ budowie walca osiowego u roślin poddanych stresowi, w porównaniu do roślin kontrolnych. 


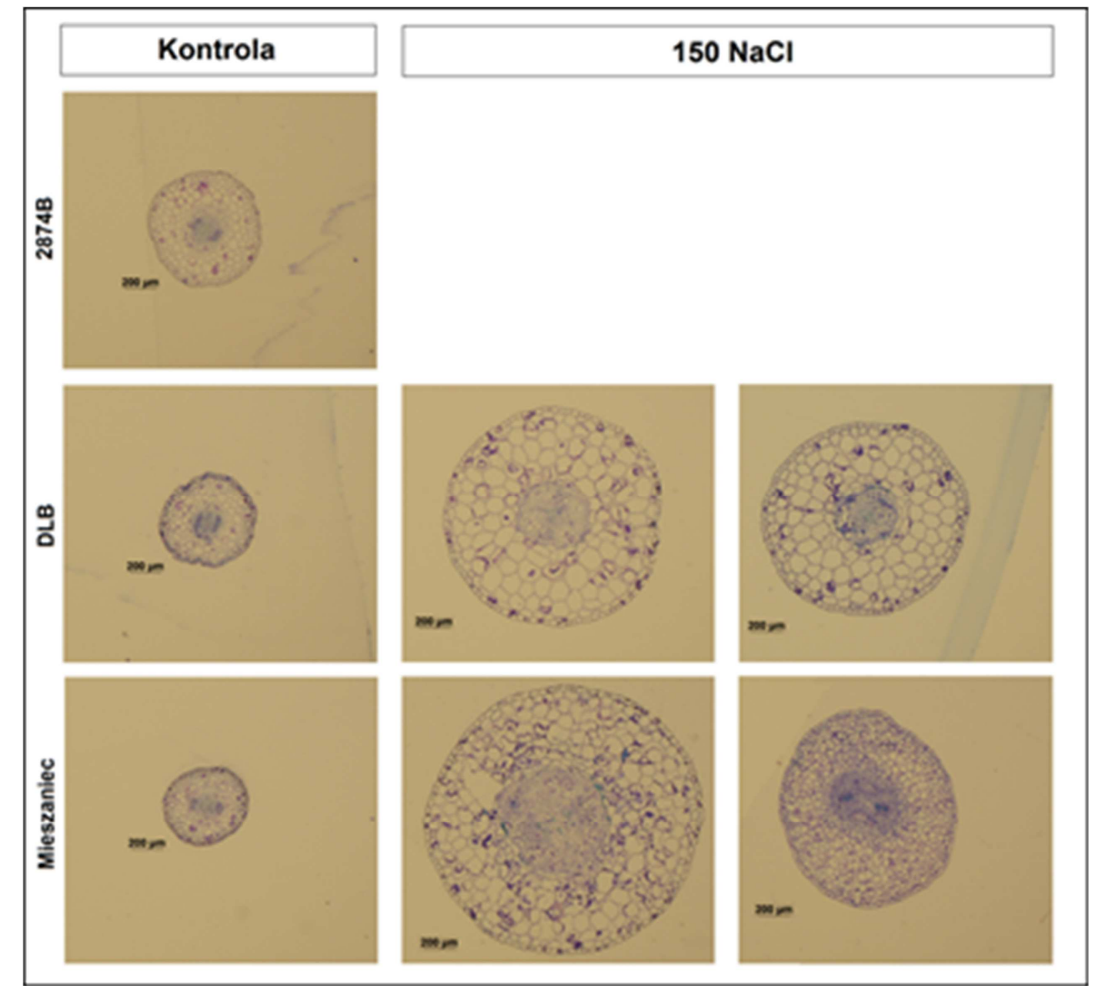

Rys. 1. Budowa anatomiczna korzeni siewek marchwi rosnących w warunkach kontrolnych (Kontrola) i w warunkach stresu zasolenia $(150 \mathrm{NaCl}) .2874 \mathrm{~B}$ - linia rodzicielska wrażliwa na stres zasolenia, DLB - rodzicielska odmiana lokalna tolerancyjna na stres zasolenia, Mieszaniec — F2 (2874B $\times$ DLB). Nie uzyskano roślin linii 2874B w warunkach stresu zasolenia

\section{Wnioski}

- Anatomia korzeni siewek marchwi tolerancyjnych na stres zasolenia rosnących na podłożu $\mathrm{z}$ dodatkiem $150 \mathrm{mM} \mathrm{NaCl}$ różni się od typowej anatomii roślin kontrolnych.

- Grubienie korzeni roślin rosnących na podłożu z dodatkiem $150 \mathrm{mM} \mathrm{NaCl}$ jest spowodowane wzrostem objętości komórek miękiszowych ( $\mathrm{w}$ przypadku roślin tolerancyjnej odmiany lokalnej DLB oraz jednej z roślin F2) lub wzrostem liczby komórek miękiszowych (w przypadku jednej z roślin F2).

- Rośliny F2 cechowały się bardziej znaczącymi nieprawidłowościami budowy anatomicznej korzenia niż tolerancyjna forma rodzicielska (DLB), obejmującymi niewłaściwie wykształcone wiązki przewodzące, przestwory między komórkami miękiszu i ich bardziej nieregularny kształt, przy czym obserwowane zmiany były różne dla każdej z roślin F2. Wskazuje to na kompleksowy charakter tolerancji na stres zasolenia, którego poszczególne komponenty u roślin F2 prawdopodobnie zostały utracone. 


\section{WYSOKOWYDAJNE GENOTYPOWANIE}

Cel tematu: genotypowanie roślin reprezentujących kolekcję odmian marchwi jadalnej w oparciu o polimorfizmy insercji transpozonów DcSto

\section{Opis wyników}

Genotypowanie w oparciu o panel markerów molekularnych DcSto zostało przeprowadzone dla 156 roślin reprezentujących 78 odmian marchwi z kolekcji zgodnie $\mathrm{z}$ metodyką opracowaną w roku 2014. Każda odmiana była reprezentowana przez jedną roślinę. Dla 73 loci otrzymano dwa warianty alleliczne odpowiadające obecności elementu DcSto lub jego brakowi. 27 loci charakteryzowało się obecnością dodatkowego wariantu allelicznego u przynajmniej jednej z genotypowanych populacji.

\section{Wnioski}

- Genotypowanie markerami DcSto 156 roślin z 78 populacji pozwoliło na identyfikację $73 \%$ loci w układzie biallelicznym, a pozostałe $23 \%$ cechowało się obecnością przynajmniej jednego dodatkowego wariantu.

\section{ANALIZA BIOINFORMATYCZNA I IDENTYFIKACJA POLIMORFIZMÓW DIAGNOSTYCZNYCH}

Cele tematu: analiza struktury zmienności genetycznej w kolekcji odmian uprawnych marchwi w oparciu o wyniki genotypowania GBS i DcSto-ILP; mapowanie asocjacyjne w oparciu o wyniki fenotypowania i genotypowania GBS; identyfikacja i charakterystyka genów kandydujących warunkujących morfologię korzenia.

\section{Opis wyników}

Wyniki uzyskane w toku genotypowania panelem markerów DcSto-ILP oraz GBS dla 78 odmian z kolekcji zmienności genetycznej marchwi uprawnej typu zachodniego zostały poddane analizom struktury zmienności genetycznej przy wykorzystaniu oprogramowania STRUCTURE. Do analizy struktury zmienności genetycznej opartej na insercjach elementów DcSto wybrano 93 loci. Analizę struktury zmienności genetycznej w oparciu o polimorfizmy pojedynczego nukleotydu przeprowadzono w oparciu o 2354 markery SNP. Stwierdzono, że najbardziej prawdopodobna struktura zmienności genetycznej badanej kolekcji odmian to:

- trzy, cztery lub siedem grup $(\mathrm{K}=3, \mathrm{~K}=4$ lub $\mathrm{K}=7)$ przy analizie struktury zmienności wynikającej z polimorfizmu insercji transpozonów DcSto;

- trzy, cztery lub pięć grup $(\mathrm{K}=3, \mathrm{~K}=4$ lub $\mathrm{K}=5)$ przy analizie struktury zmienności wynikającej z polimorfizmu pojedynczych nukleotydów (SNP).

Do przeprowadzenia genomowego mapowania asocjacyjnego (GWAS) wykorzystano 127155 polimorfizmów SNP zidentyfikowanych w wyniku genotypowania GBS dla 327 roślin reprezentujących różne grupy odmian marchwi. Zidentyfikowano rejon zlokalizowany na chromosomie 1 , zasocjowany z szerokością korzenia. W jego obrębie znajdowało się osiem markerów o wartości $-\log 10 \mathrm{e}<5,52$ i były one zlokalizowane w rejonie obejmującym dwa geny. 


\section{Wnioski}

- Struktura zmienności genetycznej populacji marchwi typu zachodniego odzwierciedla podział odmian marchwi na typy użytkowe oraz morfologię korzenia spichrzowego.

- Typy Amsterdam i Chantenay są wyraźnie odrębne od pozostałych typów.

- Przyporządkowanie odmian w oparciu o markery SNP jest nieco inne niż to obserwowane dla markerów DcSto.

- Wysoki poziom admiksji wskazuje na stosunkowo częste wykorzystywanie przez hodowców krzyżowań pomiędzy materiałami należącymi do różnych typów użytkowych.

- Przy wykorzystaniu strategii mapowania asocjacyjnego (GWAS) zidentyfikowano gen kandydujący (LOC108201261), związany z determinacją przyrostu korzenia marchwi na szerokość.

— Kształt korzenia marchwi jest determinowany poligenicznie, poprzez wiele loci charakteryzujących się małymi efektami.

\section{KONWERSJA WYBRANYCH POLIMORFIZMÓW DO MARKERÓW SPECYFICZNYCH}

Cel tematu: konwersja polimorfizmów GBS-SNP do markerów specyficznych i ich walidacja

\section{Opis wyników}

Do genotypowania w rejonie dwóch genów kandydujących (gen warunkujący przyrost korzenia marchwi na szerokość i gen potencjalnie związany z reakcją roślin marchwi na stres zasolenia) wykorzystano cztery markery SNP identyfikowane w systemie TaqMan. Przeprowadzono również ocenę poziomu ekspresji tych samych genów. Marker chr1_26632616 różnicował rośliny marchwi pod względem współczynnika kształtu korzenia w zależności od genotypu (rys. 2). Przeciwstawne allele zasocjowanego genu cechowały się podobnym profilem ekspresji, osiągając maksimum w okresie 11 tygodnia od kiełkowania, ale wzrost poziomu ekspresji dla allelu warunkującego intensywniejszy przyrost korzenia marchwi na szerokość był znacznie silniejszy niż dla allelu przeciwstawnego (rys. 2). Wskazuje to na prawdopodobny związek tego genu $\mathrm{z}$ determinacją kształtu korzenia marchwi. Trudność $\mathrm{z}$ oznaczeniem homozygot alternatywnych dla markera $\mathrm{w}$ obrębie rejonu determinującego reakcję siewek marchwi na zasolenie i ich identyfikacja jako heterozygoty w technice TaqMan, może świadczyć o istnieniu w tym rejonie strukturalnej rearanżacji. Wytypowany gen kandydujący ulegał wyciszeniu w odpowiedzi na stres zasolenia u roślin tolerancyjnych. 


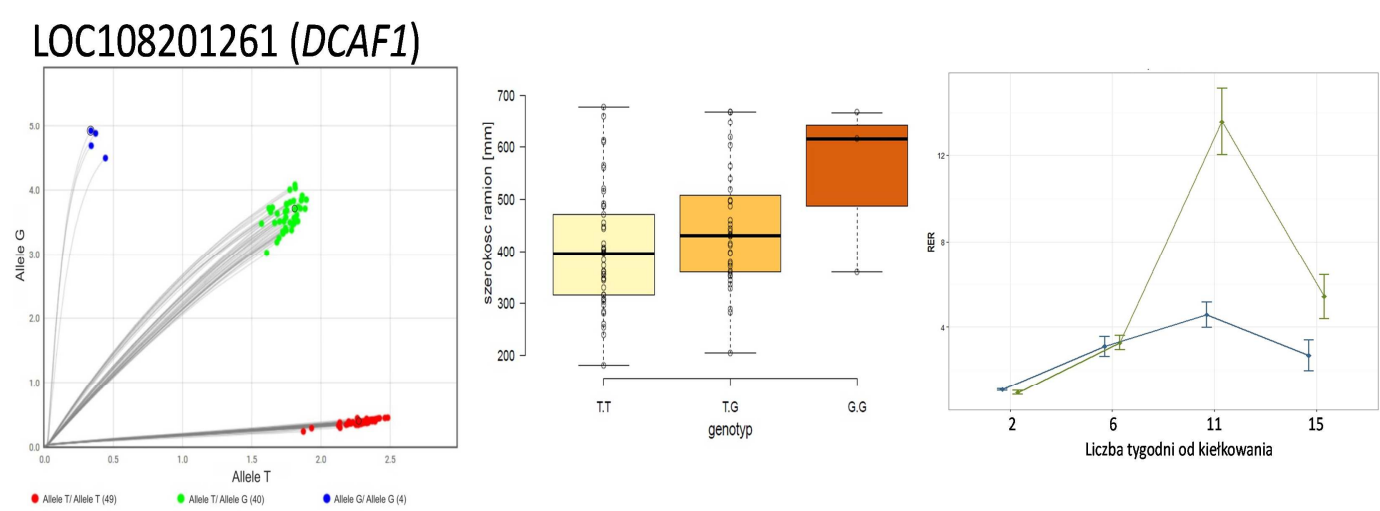

Rys. 2. Wyniki walidacji markera SNP chr1_26632616 zasocjowanego z szerokością korzenia spichrzowego marchwi. Genotypowanie 90 roślin o różnym kształcie korzenia w systemie TaqMan (lewy panel), wykres box-plot obrazujący rozkład wartości szerokości ramion dla tych samych roślin, w zależności od identyfikowanego genotypu (środkowy panel), ekspresja genu LOC108201261

w korzeniach roślin o przeciwstawnych wariantach allelicznych markera SNP chr1_26632616 (GG kolor zielony, TT - kolor niebieski) w czterech terminach odpowiadających fazom rozwojowym korzenia spichrzowego marchwi (prawy panel)

\section{Wnioski}

— Dla jednego z dwóch testowanych loci (chr1_26632616) obserwowano oczekiwany polimorfizm pojedynczego nukleotydu.

— Marker SNP chr1_26632616 identyfikowany przy użyciu technologii TaqMan wydajnie genotypował rośliny w obrębie segregujących populacji.

- Zaobserwowano statystycznie istotną różnicę pod względem szerokości korzenia pomiędzy roślinami homozygotycznymi o przeciwstawnych wariantach allelicznych markera SNP chr1 26632616.

- Gen LOC108201261 jest zaangażowany w przyrost korzenia spichrzowego na grubość, mający miejsce około 10-11 tygodnia od kiełkowania.

— Wyniki genotypowania TaqMan genu DCAR_006211 potencjalnie zaangażowanego w warunkowanie tolerancji marchwi na stres zasolenia wskazują na prawdopodobne rearanżacje (możliwą tandemową duplikację) w genotypowanym rejonie. Zastosowanie markera HRM zakotwiczonego w miejscu flankującym kwestionowany rejon pozwoliło na jednoznaczne przyporządkowanie roślin do właściwych genotypów.

— Ekspresja genu DCAR_006211 u roślin o przeciwstawnych wariantach alleliczych $\mathrm{w}$ warunkach kontrolnych była podobna. $\mathrm{U}$ roślin tolerancyjnych poddanych stresowi zasolenia (150 mM NaCl) jego ekspresja została silnie obniżona. 
